Asian J. Med. Biol. Res. 2018, 4 (2), 157-163; doi: 10.3329/ajmbr.v4i2.38250

\author{
Asian Journal of \\ Medical and Biological Research \\ ISSN 2411-4472 (Print) 2412-5571 (Online) \\ www.ebupress.com/journal/ajmbr
}

\title{
Article
}

\section{Effects of age and breed on trace elements content in cattle muscle and edible offal}

\author{
Hayrunnisa ÖZL $\ddot{U}^{1}$ and Mustafa ATASEVER ${ }^{2 *}$ \\ ${ }^{1}$ Department of Nutrition and Dietetics, Faculty of Health Sciences, Atatürk University, 25240, Erzurum, \\ Turkey \\ ${ }^{2}$ Department of Food Hygiene and Technology, Faculty of Veterinary Science, Ataturk University, 25240, \\ Erzurum, Turkey
}

*Corresponding author: Mustafa ATASEVER, Department of Food Hygiene and Technology, Faculty of Veterinary Science, Ataturk University, 25240, Erzurum, Turkey. Phone: +90 442231 7123; E-mail: atasever@atauni.edu.tr

Received: 19 February 2018/Accepted: 03 May 2018/ Published: 30 June 2018

\begin{abstract}
In this study, effects of age and breed on the trace elements content in different muscles $(M$. longissimus dorsi, M. longissimus thoracis, M. psoas major, M. intercostalis internus, M. semispinalis capitis, M. biceps femoris, M. biceps brachii) and edible offal (liver, kidney, heart) of cattle were investigated. Iron (Fe), zinc $(\mathrm{Zn})$, copper $(\mathrm{Cu})$, lead $(\mathrm{Pb})$ and cadmium $(\mathrm{Cd})$ contents of muscles and edible offal were determined by inductively coupled plasma-optic emission spectrometry (ICP-OES).According to the results obtained in this study, the content of $\mathrm{Cu}$ in M. longissimus dorsi of Eastern Anatolian Red (EAR) breed cattle was higher than Brown Swiss (BS) breed cattle, and the content of $\mathrm{Cu}$ in M. longissimus dorsi was statistically significant among the breeds $(\mathrm{p}<0.05)$. On the other hand, the highest $\mathrm{Cu}$ content in kidney and the highest $\mathrm{Cd}$ content in liver were observed the 4-year-old cattle, and the content of $\mathrm{Cu}$ in kidney and the content of $\mathrm{Cd}$ in the liver were statistically significant among the ages $(\mathrm{p}<0,05)$. Besides, the highest contents of $\mathrm{Fe}, \mathrm{Cu}$ and $\mathrm{Cd}$ were found in the edible offal of EAR breed cattle aged 4 years. The mean values of the trace elements found in cattle muscles were ranked as $\mathrm{Zn}>\mathrm{Cu}>\mathrm{Fe}>\mathrm{Pb}>\mathrm{Cd}$, whereas the mean values of the trace elements found in edible offal of cattle were ranked as $\mathrm{Cu}>\mathrm{Fe}>\mathrm{Zn}>\mathrm{Pb}>\mathrm{Cd}$. Our results suggest that trace element content may vary in both muscles and offal depend on the breed and age of the cattle.
\end{abstract}

Keywords: cattle; edible offal; ICP-OES; muscle; trace element

\section{Introduction}

Meat and offal are not only an important source of protein, butalso of trace elements (Gerber et al., 2009). Trace elements are important micronutrients which are required in very small quantities for human diet to maintain normal physiological functions but they cannot be synthesized in the body (Gerber, 2007). The offal, such as liver, heart and kidney, are richer in trace elements compared to meat (Forte and Bocca, 2007; Reykdal and Thorlacius 2001).

The essential trace elements play an important role in biological systems, but can also make toxic effects at high concentrations ( $\mathrm{Fe}, \mathrm{Zn}, \mathrm{Cu}, \mathrm{I}, \mathrm{Mg}, \mathrm{Co}, \mathrm{Se}, \mathrm{Mo}, \mathrm{F}$, etc.). However non-essential elements are potentially toxic (Ar, Cd, Pb, Hg, etc.), even at low concentrations (Surtipanti et al., 1995; Uluozlu et al., 2009). Iron, zinc and copper are important trace nutrientsin human, animals and plants nutrition. Deficiency of these elements is generally of greater concern than their toxicity, because toxicity is only observed when very high doses are ingested (Kessler et al., 2003; Reykdal and Thorlacius, 2001; Pereira et al., 2017).

Lead and cadmium are toxic forhuman and animals. This elements are ordinary constituents of nature but due to increased industrial activities there is a growing concern for levels in tissues of plants and animals consumed by 
human. Concentrations of lead and cadmium in meat are considerably lower than in kidney and liver (Reykdal and Thorlacius, 2001; Pilarczyk, 2017).

The aim of this study was to determine effects of age and breed on the contents of $\mathrm{Fe}, \mathrm{Zn}, \mathrm{Cu}, \mathrm{Pb}$ and $\mathrm{Cd}$ in the muscles and edible offal of cattle.

\section{Materials and Methods}

\subsection{Samples}

A total of 110 samples from seven different muscles (M. longissimus dorsi, M. longissimus thoracis, M. psoas major, M. intercostalis internus, M. semispinalis capitis, M. biceps femoris, M. biceps brachii) and three different edible offal (liver, kidney and heart) of 7 EAR and 3 BS breed cattle were collected from Erzurum slaughter house in Turkey. The cattle were different ages (2, 3 and 4) and, samples were taken from the same cattle. All samples were put into plastic bags for transport to the laboratory on the same day and were stored at $-18^{\circ} \mathrm{C}$ until used to analysis.

\subsection{Microwave digestion}

The samples were digested by a commercial Microwave Digestion System (Berghof Speedwave MWS-3) using vessels that are pressure resistant and manufactured entirely from is statically pressed TFM. Approximately 0.5 g sample was weighted and mixed with $6 \mathrm{ml} \mathrm{HNO}_{3}(65 \%)$ and $2 \mathrm{ml} \mathrm{H}_{2} \mathrm{O}_{2}(35 \%)$ in a vessel. Blank digestion was carried out in the same way. First, digestion temperature was raised to $180^{\circ} \mathrm{C}$ within 15 minutes and held at this temperature for 15 minutes. After then, digested samples cooling, the content of the vessels were diluted to $25 \mathrm{ml}$ with double deionized water (Gerber, 2007).

\subsection{Trace elements analysis}

Inductively coupled plasma-optic emission spectrometry (ICP-OES) was used to determine iron, zinc, copper, lead and cadmium contents in the muscle and offal samples of cattle. The Spectrometer (Optima 2000 DV Perkin Elmer-1350 W) was used with the following wavelengths: $238.204 \mathrm{~nm}$ for iron, $213.857 \mathrm{~nm}$ for zinc, 324.752 $\mathrm{nm}$ for copper, $224.688 \mathrm{~nm}$ for lead and $226.502 \mathrm{~nm}$ for cadmium. All trace element contents were determined on a wet weight basis.

\subsection{Statistical analysis}

All statistical analyses were performed using SPSS 13.0 software package. All data are presented as average values \pm SD. All variables were tested with one way Analysis of Variance (ANOVA) followed by Duncan's test. Independent-samples t-test was used to compare data between the two breed. Results were considered as significant when p-values were than 0.05 .

\section{Results}

The mean values of $\mathrm{Fe}, \mathrm{Zn}, \mathrm{Cu}, \mathrm{Pb}$ and $\mathrm{Cd}$ contents $(\mathrm{mg} / \mathrm{kg}$ ) in seven different muscles (M. longissimus dorsi, M. longissimus thoracis, M. psoas major, M. intercostalis internus, M. semispinalis capitis, M. biceps femoris, M. biceps brachii) and three different edible offal (liver, kidney and heart) of cattle depending on the age (2, $3,4)$ and breed (SB, EAR) are given in Tables 1 and 2.

Although there were not significant differences in the Fe content among the age and breed groups, $\mathrm{Fe}$ concentration varied appreciably among the age and breed groups in the current study. The lowest and the highest content of $\mathrm{Fe}$ in muscles depend on breed were identified in $M$. longissimus dorsi $(18.85 \mathrm{mg} / \mathrm{kg})$ and $M$. biceps brachii $(42.39 \mathrm{mg} / \mathrm{kg}$ ) of BS breed cattle. At the same time, the highest and lowest Fe content was in $M$. longissimus dorsi of 3 and 4-year-old cattle $(45.26 \mathrm{mg} / \mathrm{kg}, 10.14 \mathrm{mg} / \mathrm{kg}$, respectively). The maximum content of $\mathrm{Zn}$ in muscle were M. biceps femoris $(87.87 \mathrm{mg} / \mathrm{kg})$ in 4 years old cattle as well as M. biceps brachii $(76.61$ $\mathrm{mg} / \mathrm{kg}$ ) in BS breed cattle. According to the results obtained in this study, the content of $\mathrm{Cu}$ in M. longissimus dorsi of EAR breed cattle was higher than BS breed cattle, and the content of $\mathrm{Cu}$ in M. longissimus dorsi was statistically significant among the breeds $(\mathrm{p}<0.05)$ (Table 1$)$.

The results showed that the highest Fe content was in kidney of the 4-year-old cattle $(84.25 \mathrm{mg} / \mathrm{kg})$ and in heart of the BS breed cattle $(70.34 \mathrm{mg} / \mathrm{kg})$. On the other hand, the lowest Fe content in the offal samples was determined in the liver of the 3 years cattle and, in liver of BS breed cattle. The lowest and the highest levels of $\mathrm{Zn}$ in edible offal depending on age were found in kidney samples in the 3 and 4 years of age in cattle, respectively. Besides, according to breed, the maximum and minimum $\mathrm{Zn}$ levels in the offal samples were determined as $23.51 \mathrm{mg} / \mathrm{kg}$ for heart of EAR breed cattle and as $49.52 \mathrm{mg} / \mathrm{kg}$ for kidney of BS. On the other hand, the highest $\mathrm{Cu}$ content in kidney and the highest $\mathrm{Cd}$ content in liver were observed the 4-year-old cattle, 
and the content of $\mathrm{Cu}$ in kidney and the content of $\mathrm{Cd}$ in the liver were statistically significant among the ages $(\mathrm{p}<0.05)$ (Table 2).

Table 1. Content of trace elements $(\mathrm{mg} / \mathrm{kg}$ ) in the muscles of cattle depending on the age and breed (mean \pm standard devation).

\begin{tabular}{|c|c|c|c|c|c|c|}
\hline \multirow{2}{*}{ Muscles } & \multirow{2}{*}{$\begin{array}{l}\text { Trace } \\
\text { Elements }\end{array}$} & \multicolumn{3}{|c|}{ Age } & \multicolumn{2}{|c|}{ Breed } \\
\hline & & 2 & 3 & 4 & BS & EAR \\
\hline \multirow{5}{*}{ 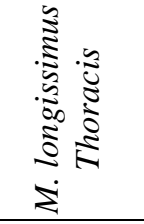 } & $\mathrm{Fe}$ & $32.52 \pm 43.96$ & $11.79 \pm 11.36$ & $32.46 \pm 37.77$ & $31.58 \pm 44.60$ & $24.15 \pm 29.33$ \\
\hline & $\mathrm{Zn}$ & $56.45 \pm 42.11$ & $45.46 \pm 3.90$ & $56.82 \pm 55.27$ & $64.42 \pm 35.56$ & $47.40 \pm 41.34$ \\
\hline & $\mathrm{Cu}$ & $48.20 \pm 14.19$ & $49.42 \pm 19.85$ & $44.34 \pm 9.04$ & $47.16 \pm 18.38$ & $47.11 \pm 10.61$ \\
\hline & $\mathrm{Pb}$ & $0.13 \pm 0.13$ & $0.12 \pm 0.07$ & $0.12 \pm 0.15$ & $0.16 \pm 0.13$ & $0.10 \pm 0.11$ \\
\hline & $\mathrm{Cd}$ & $0.02 \pm 0.01$ & $0.06 \pm 0.06$ & $0.05 \pm 0.07$ & $0.06 \pm 0.05$ & $0.03 \pm 0.06$ \\
\hline \multirow{5}{*}{ 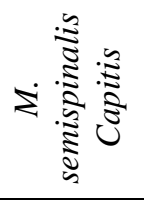 } & $\mathrm{Fe}$ & $21.94 \pm 32.96$ & $12.96 \pm 7.43$ & $33.38 \pm 48.88$ & $23.77 \pm 31.81$ & $23.59 \pm 37.05$ \\
\hline & $\mathrm{Zn}$ & $44.82 \pm 27.30$ & $45.03 \pm 10.83$ & $58.12 \pm 67.50$ & $54.76 \pm 22.46$ & $46.83 \pm 49.85$ \\
\hline & $\mathrm{Cu}$ & $50.06 \pm 16.67$ & $51.05 \pm 31.32$ & $39.13 \pm 21.97$ & $42.05 \pm 26.58$ & $48.82 \pm 19.74$ \\
\hline & $\mathrm{Pb}$ & $0.11 \pm 0.08$ & $0.10 \pm 0.09$ & $0.17 \pm 0.26$ & $0.11 \pm 0.11$ & $0.14 \pm 0.19$ \\
\hline & $\mathrm{Cd}$ & $0.01 \pm 0.01$ & $0.02 \pm 0.02$ & $0.03 \pm 0.02$ & $0.02 \pm 0.02$ & $0.02 \pm 0.02$ \\
\hline \multirow{5}{*}{ 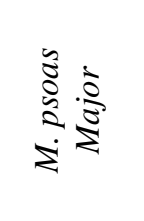 } & $\mathrm{Fe}$ & $19.82 \pm 26.42$ & $10.28 \pm 9.71$ & $30.05 \pm 41.95$ & $19.13 \pm 26.87$ & $21.97 \pm 31.77$ \\
\hline & $\mathrm{Zn}$ & $29.43 \pm 25.39$ & $30.34 \pm 10.15$ & $77.43 \pm 102.17$ & $32.57 \pm 22.03$ & $55.46 \pm 77.93$ \\
\hline & $\mathrm{Cu}$ & $41.65 \pm 27.30$ & $44.46 \pm 20.86$ & $85.47 \pm 86.01$ & $31.85 \pm 8.76$ & $73.50 \pm 64.92$ \\
\hline & $\mathrm{Pb}$ & $0.13 \pm 0.13$ & $0.09 \pm 0.05$ & $0.42 \pm 0.70$ & $0.11 \pm 0.13$ & $0.29 \pm 0.52$ \\
\hline & $\mathrm{Cd}$ & $0.02 \pm 0.01$ & $0.01 \pm 0.01$ & $0.03 \pm 0.03$ & $0.02 \pm 0.01$ & $0.02 \pm 0.02$ \\
\hline \multirow{5}{*}{ 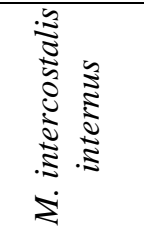 } & $\mathrm{Fe}$ & $26.35 \pm 34.59$ & $17.35 \pm 13.57$ & $37.08 \pm 56.31$ & $26.38 \pm 34.60$ & $28.61 \pm 41.93$ \\
\hline & $\mathrm{Zn}$ & $43.30 \pm 46.55$ & $42.69 \pm 8.88$ & $66.82 \pm 85.79$ & $50.34 \pm 44.92$ & $52.45 \pm 63.40$ \\
\hline & $\mathrm{Cu}$ & $41.46 \pm 20.09$ & $51.64 \pm 13.92$ & $46.72 \pm 28.70$ & $46.76 \pm 19.87$ & $45.80 \pm 22.60$ \\
\hline & $\mathrm{Pb}$ & $0.19 \pm 0.14$ & $0.10 \pm 0.04$ & $0.22 \pm 0.38$ & $0.19 \pm 0.14$ & $0.16 \pm 0.28$ \\
\hline & $\mathrm{Cd}$ & $0.01 \pm 0.01$ & $0.01 \pm 0.01$ & $0.04 \pm 0.03$ & $0.02 \pm 0.01$ & $0.03 \pm 0.03$ \\
\hline \multirow{5}{*}{ 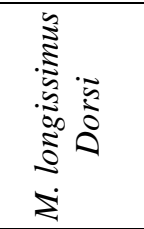 } & $\mathrm{Fe}$ & $20.52 \pm 22.69$ & $10.14 \pm 8.72$ & $45.26 \pm 75.54$ & $18.85 \pm 23.61$ & $31.17 \pm 56.44$ \\
\hline & $\mathrm{Zn}$ & $31.68 \pm 28.26$ & $26.50 \pm 1.71$ & $70.41 \pm 104.56$ & $31.54 \pm 26.90$ & $51.68 \pm 77.79$ \\
\hline & $\mathrm{Cu}$ & $55.38 \pm 31.38$ & $48.30 \pm 1.69$ & $89.38 \pm 41.50$ & $39.92 \pm 12.09 b$ & $80.61 \pm 34.28 \mathrm{a}$ \\
\hline & $\mathrm{Pb}$ & $0.17 \pm 0.07$ & $0.11 \pm 0.02$ & $0.43 \pm 0.60$ & $0.15 \pm 0.07$ & $0.30 \pm 0.45$ \\
\hline & $\mathrm{Cd}$ & $0.02 \pm 0.01$ & $0.02 \pm 0.01$ & $0.08 \pm 0.06$ & $0.02 \pm 0.01$ & $0.06 \pm 0.06$ \\
\hline \multirow{5}{*}{ 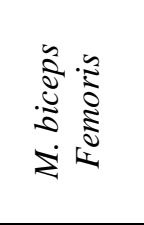 } & $\mathrm{Fe}$ & $24.64 \pm 32.29$ & $11.90 \pm 10.19$ & $44.50 \pm 68.85$ & $23.79 \pm 32.97$ & $31.02 \pm 51.76$ \\
\hline & $\mathrm{Zn}$ & $38.77 \pm 28.14$ & $31.18 \pm 8.78$ & $87.87 \pm 133.06$ & $42.62 \pm 26.59$ & $61.38 \pm 99.75$ \\
\hline & $\mathrm{Cu}$ & $32.77 \pm 19.50$ & $36.33 \pm 12.03$ & $65.22 \pm 58.03$ & $34.91 \pm 20.52$ & $51.61 \pm 44.75$ \\
\hline & $\mathrm{Pb}$ & $0.14 \pm 0.13$ & $0.07 \pm 0.07$ & $0.46 \pm 0.71$ & $0.16 \pm 0.12$ & $0.28 \pm 0.55$ \\
\hline & $\mathrm{Cd}$ & $0.02 \pm 0.01$ & $0.01 \pm 0.01$ & $0.06 \pm 0.08$ & $0.02 \pm 0.01$ & $0.04 \pm 0.07$ \\
\hline \multirow{5}{*}{ 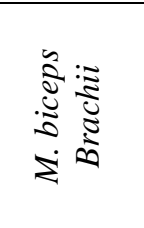 } & $\mathrm{Fe}$ & $40.26 \pm 49.86$ & $22.88 \pm 7.94$ & $34.91 \pm 51.58$ & $42.39 \pm 48.43$ & $29.97 \pm 36.74$ \\
\hline & $\mathrm{Zn}$ & $71.91 \pm 48.69$ & $62.16 \pm 4.09$ & $78.64 \pm 94.44$ & $76.61 \pm 46.17$ & $68.89 \pm 68.10$ \\
\hline & $\mathrm{Cu}$ & $31.85 \pm 17.52$ & $34.44 \pm 13.74$ & $53.20 \pm 38.00$ & $31.52 \pm 17.91$ & $45.35 \pm 29.54$ \\
\hline & $\mathrm{Pb}$ & $0.10 \pm 0.16$ & $0.17 \pm 0.02$ & $0.26 \pm 0.39$ & $0.13 \pm 0.15$ & $0.16 \pm 0.31$ \\
\hline & $\mathrm{Cd}$ & $0.02 \pm 0.02$ & $0.02 \pm 0.01$ & $0.05 \pm 0.04$ & $0.02 \pm 0.01$ & $0.03 \pm 0.03$ \\
\hline \multirow{5}{*}{ Mean } & $\mathrm{Fe}$ & $26.58 \pm 32.31$ & $13.90 \pm 9.48$ & $37.16 \pm 49.36$ & $26.56 \pm 32.45$ & $27.21 \pm 39.24$ \\
\hline & $\mathrm{Zn}$ & $45.20 \pm 35.03$ & $40.48 \pm 13.30$ & $70.87 \pm 84.32$ & $50.41 \pm 33.37$ & $54.87 \pm 66.49$ \\
\hline & $\mathrm{Cu}$ & $43.05 \pm 20.87$ & $45.09 \pm 16.70$ & $60.49 \pm 45.43$ & $39.17 \pm 17.49$ & $56.11 \pm 36.69$ \\
\hline & $\mathrm{Pb}$ & $0.14 \pm 0.11$ & $0.09 \pm 0.06$ & $0.30 \pm 0.46$ & $0.15 \pm 0.11$ & $0.21 \pm 0.36$ \\
\hline & $\mathrm{Cd}$ & $0.02 \pm 0.01$ & $0.02 \pm 0.03$ & $0.05 \pm 0.05$ & $0.02 \pm 0.02$ & $0.03 \pm 0.04$ \\
\hline
\end{tabular}

$\mathrm{a}-\mathrm{b}$ : Means followed by different letters in the same line are significantly different $(\mathrm{p}<0.05)$ according to Independentsamples t-test; for statistical analysis. 
Table 2. Content of trace elements $(\mathrm{mg} / \mathrm{kg})$ in the edible offal of cattle depending on the age and breed (mean \pm standard deviation).

\begin{tabular}{cllllll}
\hline \multirow{2}{*}{ Offal } & Trace & \multicolumn{3}{c}{ Age } & \multicolumn{2}{c}{ Breed } \\
\cline { 2 - 7 } & Elements & $\mathbf{2}$ & $\mathbf{3}$ & $\mathbf{4}$ & BS & EAR \\
\hline \multirow{3}{*}{ Liver } & $\mathrm{Fe}$ & $38.63 \pm 23.95$ & $25.25 \pm 7.33$ & $56.79 \pm 42.96$ & $35.19 \pm 25.87$ & $45.23 \pm 33.81$ \\
& $\mathrm{Zn}$ & $29.70 \pm 24.96$ & $21.22 \pm 5.83$ & $42.92 \pm 34.02$ & $34.43 \pm 21.58$ & $30.91 \pm 28.36$ \\
& $\mathrm{Cu}$ & $80.66 \pm 22.63$ & $44.66 \pm 18.09$ & $70.48 \pm 2.77$ & $64.94 \pm 23.07$ & $68.40 \pm 21.91$ \\
& $\mathrm{~Pb}$ & $0.25 \pm 0.10$ & $0.12 \pm 0.09$ & $0.25 \pm 0.14$ & $0.24 \pm 0.11$ & $0.20 \pm 0.13$ \\
& $\mathrm{Cd}$ & $0.04 \pm 0.03 \mathrm{~b}$ & $0.01 \pm 0.01 \mathrm{~b}$ & $0.08 \pm 0.05 \mathrm{a}$ & $0.02 \pm 0.02$ & $0.06 \pm 0.05$ \\
\hline \multirow{6}{*}{ Heart } & $\mathrm{Fe}$ & $73.71 \pm 79.53$ & $35.30 \pm 13.06$ & $68.59 \pm 46.41$ & $70.34 \pm 81.71$ & $56.25 \pm 36.75$ \\
& $\mathrm{Zn}$ & $43.75 \pm 41.35$ & $20.92 \pm 11.33$ & $31.23 \pm 45.73$ & $49.52 \pm 36.35$ & $23.51 \pm 33.88$ \\
& $\mathrm{Cu}$ & $56.25 \pm 11.08$ & $64.62 \pm 15.22$ & $36.01 \pm 33.11$ & $61.37 \pm 16.94$ & $45.35 \pm 26.37$ \\
& $\mathrm{~Pb}$ & $0.17 \pm 0.15$ & $0.11 \pm 0.01$ & $0.17 \pm 0.26$ & $0.18 \pm 0.15$ & $0.14 \pm 0.19$ \\
Kidne & $\mathrm{Zn}$ & $6.03 \pm 0.02$ & $0.06 \pm 0.07$ & $0.03 \pm 0.01$ & $0.05 \pm 0.06$ & $0.03 \pm 0.02$ \\
\hline $\mathrm{y}$ & $\mathrm{Fu}$ & $23.77 \pm 27.01$ & $13.69 \pm 1.82$ & $69.65 \pm 99.69$ & $26.97 \pm 24.56$ & $43.84 \pm 77.53$ \\
& $\mathrm{~Pb}$ & $49.11 \pm 2.21 \mathrm{~b}$ & $32.22 \pm 10.63 \mathrm{~b}$ & $70.64 \pm 19.68 \mathrm{a}$ & $38.39 \pm 14.18$ & $60.30 \pm 19.03$ \\
& $\mathrm{Cd}$ & $0.13 \pm 0.11$ & $0.06 \pm 0.02$ & $0.22 \pm 0.25$ & $0.11 \pm 0.11$ & $0.16 \pm 0.19$ \\
\hline
\end{tabular}

a-b: Means followed by different letters in the same line are significantly different $(\mathrm{p}<0.05)$ according to Duncan's test; for statistical analysis.

Table 3. Content of trace elements $(\mathrm{mg} / \mathrm{kg})$ in the muscles and edible offal (mean \pm standard devation).

\begin{tabular}{llllll}
\hline Samples & Fe & Zn & Cu & Pb & Cd \\
\hline Liver & $41.58 \pm 30.21$ & $32.19 \pm 25.01$ & $67.14 \pm 21.23$ & $0.22 \pm 0.12$ & $0.05 \pm 0.04$ \\
Kidney & $61.37 \pm 53.51$ & $32.97 \pm 35.46$ & $51.17 \pm 23.85$ & $0.15 \pm 0.17$ & $0.04 \pm 0.04$ \\
Heart & $60.95 \pm 51.02$ & $37.71 \pm 62.13$ & $52.34 \pm 20.00$ & $0.14 \pm 0.16$ & $0.16 \pm 0.26$ \\
\hline M. longissimus thoracis & $26.85 \pm 33.57$ & $53.59 \pm 38.45$ & $47.13 \pm 13.00$ & $0.13 \pm 0.12$ & $0.04 \pm 0.05$ \\
M. semispinalis capitis & $23.65 \pm 33.57$ & $49.71 \pm 40.72$ & $46.36 \pm 21.39$ & $0.13 \pm 0.16$ & $0.02 \pm 0.02$ \\
M. psoas major & $20.94 \pm 28.71$ & $47.13 \pm 62.63$ & $58.35 \pm 54.71$ & $0.22 \pm 0.42$ & $0.02 \pm 0.02$ \\
M. intercostalis internus & $27.80 \pm 37.62$ & $51.69 \pm 54.94$ & $46.15 \pm 20.62$ & $0.17 \pm 0.23$ & $0.02 \pm 0.03$ \\
M. longissimus dorsi & $26.69 \pm 46.01$ & $44.35 \pm 62.86$ & $65.81 \pm 34.21$ & $0.25 \pm 0.36$ & $0.04 \pm 0.05$ \\
M. biceps femoris & $28.39 \pm 44.12$ & $54.56 \pm 79.20$ & $45.54 \pm 37.40$ & $0.24 \pm 0.43$ & $0.03 \pm 0.05$ \\
M. biceps brachii & $34.49 \pm 39.40$ & $71.70 \pm 58.63$ & $40.32 \pm 25.85$ & $0.15 \pm 0.25$ & $0.03 \pm 0.03$ \\
Mean & $26.97 \pm 36.68$ & $53.25 \pm 56.50$ & $49.95 \pm 32.04$ & $0.18 \pm 0.30$ & $0.03 \pm 0.04$ \\
\hline
\end{tabular}

Trace element concentrations in muscle and offal samples were quite variable as Fe: 10.14-45.26; $25.25-84.25$ $\mathrm{mg} / \mathrm{kg}, \mathrm{Zn}: 26.50-87.87 ; 13.69-69.65 \mathrm{mg} / \mathrm{kg}, \mathrm{Cu}: 31.85-89.38 ; 32.22-80.66 \mathrm{mg} / \mathrm{kg}, \mathrm{Pb}: 0.07-0.46 ; 0.06-0.25$ $\mathrm{mg} / \mathrm{kg}$, Cd: $0.01-0.08 ; 0.01-0.30 \mathrm{mg} / \mathrm{kg}$, respectively. The order of trace element levels determined in muscle and offal samples were $\mathrm{Zn}>\mathrm{Cu}>\mathrm{Fe}>\mathrm{Pb}>\mathrm{Cd}$ and $\mathrm{Cu}>\mathrm{Fe}>\mathrm{Zn}>\mathrm{Pb}>\mathrm{Cd}$, respectively (Table 3).

\section{Discussion}

Trace elements are essential food components that are not synthesized in the body and must be absolutely taken in from the outside sources. The most reliable and healthy way of taking in these elements from outside of the body is with food. The sufficient intake of the trace elements needed by the human body can only be supplied with adequate and balanced nutrition (Gropper et al., 2016). Red meat, considered as one of the good food sources for nutrition, is very rich in essential trace elements for the human organism, except for calcium (De Smet and Vossen, 2016; Lombardi-Boccia et al., 2005). In this study, in which the effects of age and breed on the content of trace elements in cattle muscle and edible offal were investigated. The content of $\mathrm{Cu}$ in $M$. longissimus dorsi was statistically significant among the breeds, and the content of $\mathrm{Cu}$ and $\mathrm{Cd}$ in the liver was statistically significant among the ages $(\mathrm{p}<0.05)$. On the other hand, the highest contents of $\mathrm{Fe}, \mathrm{Cu}$ and $\mathrm{Cd}$ were found in the edible offal of EAR breed cattle aged 4 years. The mean values of the trace elements found in cattle muscles were ranked as $\mathrm{Zn}>\mathrm{Cu}>\mathrm{Fe}>\mathrm{Pb}>\mathrm{Cd}$, whereas the mean values of the trace elements found in edible offal of cattle were ranked as $\mathrm{Cu}>\mathrm{Fe}>\mathrm{Zn}>\mathrm{Pb}>\mathrm{Cd}$.

The Fe content of muscles obtained from this study were higher than Fe content in muscles Kotula and Lusby, 1982, but were lower than those recorded by Demirel et al.,2008 and López Alonso et al., 2004. Furthermore, 
the mean $\mathrm{Zn}$ content in liver observed in this study was lower than those reported by Sedki et al., 2003 and López-Alonso et al., 2004. Although $\mathrm{Fe}, \mathrm{Zn}, \mathrm{Pb}$ and $\mathrm{Cd}$ contents found in the cattle muscles and livers in this study were higher than the values obtained by Surtipanti el al., 1995, they were found to be lower than the values obtained by Koréneková and Skalıcká, 2002.

Moreover, it was observed that the values of $\mathrm{Fe}$ in the muscles, and $\mathrm{Cu}, \mathrm{Pb}, \mathrm{Cd}$ in the livers, and $\mathrm{Pb}$ and $\mathrm{Cd}$ in the kidneys of the cattle fattened up in rural areas were higher in the study conducted by Abou-Arab, 2001 than the values obtained in this study. Although the trace element content that was identified by the same researcher in the livers of the cattle fattened up in industrialized areas was the same as that of the cattle fattened up in rural areas, the contents of $\mathrm{Fe}$ along with $\mathrm{Zn}$ in the muscles, the contents of $\mathrm{Pb}$ and $\mathrm{Cd}$ in addition to $\mathrm{Fe}$ and $\mathrm{Zn}$ in the kidneys, and the contents of $\mathrm{Pb}$ and $\mathrm{Cd}$ in the hearts of the cattle were found to be higher than the values we obtained in our study.

These studies conducted show that the difference in the contents of trace elements and heavy metals found in the muscle and edible offal of the cattle may be caused due to regional differences, on the other hand, may result in more accumulation in particular organs, especially in the liver and kidneys of animals fattened up close to industrial areas. This can be explained by the soil characteristics of the region, as well as the contamination status of pasture lands and waters with industrial wastes (Tangahu et al., 2011; Trujillo-González et al., 2017). It was observed that the amounts of $\mathrm{Pb}$ and $\mathrm{Cd}$ found in the cattle liver and kidney tissues were higher in the study of Şenavc1 et al., 1997 that was conducted in Ankara and Bursa cities than the values we obtained in our study. This difference is explained by the study regions of the researchers which were much more intense than our study area in terms of both vehicular traffic and industrialization.

The partially polluted and highly polluted categories of $\mathrm{Cd}$ and $\mathrm{Mn}$ values according to a study conducted on the metal content of the Ankara streamlet (Başar, 2001) and the $\mathrm{Pb}, \mathrm{Ni}, \mathrm{Cr}$ and $\mathrm{Sb}$ values of the agricultural soils in South Marmara above the limit values support the result of the high amounts of $\mathrm{Pb}$ and $\mathrm{Cd}$ in the liver and kidney tissues of the cattle fattened up in the region (Dartan and Toröz, 2013). It is considered that the exposure of the soil and waters of the region to these heavy metals, especially by the effects of industrial wastes and exhaust gases which have a high heavy metal content, may cause an accumulation in certain organs of plants and animals in the region (Oymak et al., 2009; Tangahu et al., 2011).

The amount of $\mathrm{Zn}$ in the cattle muscles found in our study was very similar to the values obtained by López Alonso et al., 2000, whereas the amounts of $\mathrm{Cu}$ in the muscle, liver and kidney tissues we found were much higher than the values obtained by López Alonso et al., 2000 and Surtipanti et al., 1995. In addition, in a study by Leonhardt et al., 2006, Fe content in cattle M. longissimus dorsi was lower than Fe content in our study, on the contrary, $\mathrm{Zn}$ content was higher.

Moreover, level of $\mathrm{Zn}$ in meat was found very high $(210 \pm 86 \mathrm{mg} / \mathrm{kg})$ in the study conducted by Batista et al., 2006. These differences in the trace element contents of the muscles and edible offal of the cattle are considered to be changing by the effects of factors such as biological (eg, family, breed, sex, age, muscle) and ecological (eg, type of fattening, place of fattening, season) factors. On the other hand, it was found that the amount of Fe in the cattle meat found in the study of Demirel et al., 2008 was much higher than the value we obtained in this study, and the amounts of $\mathrm{Zn}$ and $\mathrm{Cu}$ were lower than in our study. Furthermore, in muscle of cattle determined the lowest $\mathrm{Cu}$ value $(31.85 \mathrm{mg} / \mathrm{kg}$ ) was higher than those reported many researcher (Domaradzki et al., 20016; Doornenbal and Murray, 1981; Huerta-Montauti et al., 2007; López Alonso et al., 2000; Marchello et al., 1984). This shows that there may be differences in different geographies, even in the same geographical region of a country, and that it makes it very difficult to standardize the trace element contents and to directly compare each other (Yildirm, 1992).

The foods of vegetable and animal origin exposed to heavy metals may result in toxication by accumulating in certain organs as a result of being consumed by animals and humans. Our study also found that higher amounts of $\mathrm{Cd}$ and $\mathrm{Pb}$ accumulated in the cattle organs, such as liver and kidney, than in the muscles. It has been indicated by the European Commission Regulation (Anonymous, 2014; Anonymous, 2015) and Turkish Food Codex Regulation (Anonymous, 2012) that the maximum acceptable amount of $\mathrm{Pb}$ in the cattle meat and edible offal is 0,10 and $0,50 \mathrm{mg} / \mathrm{kg}$, respectively, and the maximum acceptable amount of $\mathrm{Cd}$ in the cattle meat and liver is $0,05 \mathrm{mg} / \mathrm{kg}$ and in the kidney is $1.00 \mathrm{mg} / \mathrm{kg}$. In this study, the amount of $\mathrm{Pb}$ in the analyzed samples was found to be above the limit values only in the meats. The value of $\mathrm{Cd}$ was found to be below these limits in both organs and meat.

\section{Conclusions}

A significant portion of daily recommended trace elements can be met by the consumption of meat and edible offal of the cattle fattened up in suitable environments, and they are particularly rich sources of iron, zinc and 
copper in terms of human nutrition. The trace element content of cattle muscle and organs is considered to vary depending on the family, breed, gender, age, fattening pattern of the animal and on ecological and geographical characteristics of the region in which the animal is fattened up. It should not be ignored that the toxicities resulting from the consumption of the meat and organs of the cattle, which are not fattened up under suitable conditions, will reach to an extent that threatens the public health. In order to prevent this condition, it is highly important to take measures in terms of reducing the heavy metal spread of factories, and to ensure that industrial enterprises are not established in areas close to agricultural lands.

\section{Acknowledgements}

The authors are grateful for the financial support of the Unit of the Scientific Research Projects of Atatürk University. This study is in part of Mrs. Ozlu's MS thesis.

\section{Conflict of interest}

None to declare.

\section{References}

Abou-Arab AAK, 2001. Heavy metals contents in Egyptian meat and the role of detergent washing of their levels. Food Chem. Toxicol., 39: 593-599.

Anonymous, 2012. Notifications about determination of the maximum levels for certain contaminants in foodstuffs of Turkish Food Codex (in Turkish). Official Gazette of Republic of Turkey, Issue, 28157.

Anonymous, 2014. Commission Regulation (EU) No 488/2014 of 12 May 2014 amending Regulation (EC) No 1881/2006 as regards maximum levels of cadmium in foodstuffs. Off. J. Eur. UnionL., 138: 75-79.

Anonymous, 2015. Commission Regulation (EU) 2015/1005 of 25 June 2015 amending Regulation (EC) No 1881/2006 as regards maximum levels of lead in certain foodstuffs. Off. J. Eur. UnionL., 161:9-13.

Başar H, 2001. Bursa ili topraklarının verimlilik durumlarının toprak analizleri ile incelenmesi. Uludag Üniv. Ziraat Fak. Derg., 15: 69-83.

Batista BL, D Grotto, MF Carneiro and FJr Barbosa, 2012. Evaluation of the concentration of nonessential and essential elements in chicken, pork, and beef samples produced in Brazil. J. Toxicol. Environ. Health A, 75: $1269-1279$.

Dartan G and İ Toröz, 2013. Güney Marmara Bölgesinde Tarım Topraklarında Ağır Metal Kirliliğinin Araştırılması. Marmara Fen Bilimleri Dergisi, 25: 24-40.

Demirel Ş, M Tüzen, S Saraçoğlu and M Soylak, 2008. Evaluation of various digestion procedures for trace element contents of some food materials. J. Hazard Mater., 152: 1020-1026.

De Smet S and E Vossen, 2016. Meat: The balance between nutrition and health. A review. Meat Sci., 120 (Supplement C): 45-156.

Domaradzki P, M Florek, A Staszowska and Z Litwińczuk, 2016. Evaluation of the mineral concentration in beef from polish native cattle. Biol. Trace Elem. Res., 171: 328-332.

Doornenbal H and AC Murray, 1981. Effects of age, breed and sex and muscle on certain mineral concentrations in cattle. J. Food Sci., 47: 55-58.

Forte G and B Bocca, 2007. Quantification of cadmium and lead in offal by SF-ICP-MS:Method development and uncertainty estimate. Food Chem., 105: 1591-1598.

Gerber N, 2007. The Role of Meat in Human Nutrition for the Supply with Nutrients, Particularly Functional Long-Chain n-3 Fatty Acids. Eidgenossische Technische Hochschule ETH, Degree of Doctor of Sciences, Zurich.

Gerber N, R Brogioli, B Hattendorf, MR Scheeder, C Wenk and D Günther, 2009. Variability of selected trace elements of different meat cuts determined by ICP-MS and DRC-ICP-MS. Animal, 3: 166-172.

Gropper SS, JL Smith and TP Carr, 2016. Essential Trace and Ultratrace Minerals. In: Advanced Nutrition and Human Metabolism. Edited by: Gropper SS and JL Smith, Cengage Learning, 7th ed, Boston, pp. 500-503.

Huerta-Montauti D, V Villa, L Arenas De Moreno, A. Rodas-González, M. Giuffrida-Mendoza and N. HuertaLeidenz, 2007. Proximate and mineral composition of imported versus domestic beef cuts for restaurant use in Venezuela. J. Muscle Foods, 18: 237-252.

Kessler J, I Morel, PA Dufey, A Gutzwiller, A Stern and H Geyer, 2003. Effect of organic zinc sources on performance, zinc status and carcass, meat and claw quality in fattening bulls. Livestock Prod. Sci., 81: $161-171$.

Koréneková B, M Skalıcka and P Nad, 2002. Concentration of some heavy metals in cattle reared in the vicinity of a metallurgic industry. Veterinarski Arhiv., 72: 259-267. 
Kotula AW and WR Lusby, 1982. Mineral composition of muscles of 1- to 6-year-old steers. J. Anim. Sci., 54: 544-548.

Lombardi-Boccia G, S Lanzi and A Aguzzi, 2005. Aspects of meat quality: trace elements and B vitamins in raw and cooked meats. J. Food Compos. Anal., 18: 39-46.

López Alonso M, JL Benedito, M Miranda, C Castillo, J Hernández and RF Shore, 2000. Arsenic, cadmium, lead, copper and zinc incattle from Galicia, NW Spain. Sci. Total Environ., 246: 237-248.

López Alonso M, FP Montana, M Miranda, C Castillo, J Hernández and J Luis Benedito, 2004. Interactions between toxic ( $\mathrm{As}, \mathrm{Cd}, \mathrm{Hg}$ and $\mathrm{Pb}$ ) and nutritional essential $(\mathrm{Ca}, \mathrm{Co}, \mathrm{Cr}, \mathrm{Cu}, \mathrm{Fe}, \mathrm{Mn}, \mathrm{Mo}, \mathrm{Ni}, \mathrm{Se}, \mathrm{Zn}$ ) elements in the tissues of cattle from NW Spain. BioMetals, 17: 389-397.

Marchello MJ, DB Milne and WD Slanger, 1984. Selected macro and micro minerals in ground beef and longissimus muscle. J. Food Sci., 49: 105-106.

Oymak T, Ş Tokalıoğlu, V Yılmaz, Ş Kartal and D Aydın, 2009. Determination of lead and cadmium in food samples by the coprecipitation method. Food Chem.,113: 1314-1317.

Reykdal O and A Thorlacius, 2001. Cadmium, mercury, iron, copper, manganese and zinc in the liver and kidney of the Icelandic lamb. Food Addit. Contam., 18: 960-969.

Pereira V, M López Alonso, M Miranda, JL Benedito and M García-Vaquero, 2017. Relationship between the essential and toxic element concentrations and the proximate composition of different commercial and internal cuts of young beef. Eur. Food Res. Technol., 243: 1869-1873.

Pilarczyk R, 2014. Concentrations of toxic and nutritional essential elements in meat from different beef breeds reared under intensive production systems. Biol. Trace Elem. Res.,158: 36-44.

Sedki A, N Lekouch, S Gamon and A Pineau, 2003. Toxic and essential trace metals in muscle, liver and kidney of bovines from a polluted area of Morocco. Sci. Total Environ., 317: 201-205.

Surtipanti S, S Suwirma, S Yumiarti and Y Mellawati, 1995. Determination of heavy metals in meat, intestine, liver, eggs and chicken using neutron activation analysis and atomic absorption spectrometry. Atom Indonesia, 21: 1-8.

Şenavcı V, B Gürsel, B Erdinç, S Sonal and S Seval, 1997. Ankara ve Bursa'da tüketime sunulan sığır, koyun ve kanatlı karaciğer ve böbreklerinde ağır metal $(\mathrm{Pb}, \mathrm{Cd}, \mathrm{Hg})$ kalıntı duzeylerinin araştırılması. Tarım ve Köyişleri Bakanlığı Tarımsal Araştırmalar Genel Müdürlüğü, Yayın No:30.Özel yayın No: 28 (TAGEMGY-02-K-4).

Uluozlu OD, M Tuzen, D Mendil and M Soylak, 2009. Assessment of trace element contents of chicken products from turkey. J. Hazard Mater.,163: 982-987.

Tangahu BJ, SR Sheikh Abdullah, H Basri, M Idris, N Anuar and M Mukhlisin, 2011. A review on heavy metals $(\mathrm{As}, \mathrm{Pb}$, and $\mathrm{Hg}$ ) uptake by plants through phytoremediation. Int. J. Chem. Eng., 1-31.

Trujillo-González J, J Mahecha-Pulido, M Torres-Mora, E Brevik, S Keesstra and R Jiménez-Ballesta, 2017. Impact of potentially contaminated river water on agricultural irrigated soils in an equatorial climate. Agriculture, 7: 52.

Yıldırım Y, 1992. Et endüstrisi. Yıldırım Basımevi, Ankara, 343-345. 